$\operatorname{cocos}(2003), 1560-81$

Printed in Sri Lanka

\title{
SOCIAL ACCEPTABILITY OF COCONUT-BASED AGROFORESTRY MODELS DEVELOPED TO SMALLHOLDERS IN SRI LANKA
}

\author{
W. B. K. Peiris ${ }^{a}$, M. T. N. Fernando ${ }^{b}$, H. M. G. S. B. Hitinayake ${ }^{c}$, \\ K. B. Dassanayake, H. A. J. Gunathilake ${ }^{b}$ and S. D. J. N. Subasinghe \\ ' HARDY Advanced Technical Institute, Inginiyagala Road, Ampara, Sri Lanka, \\ ${ }^{b}$ Coconut Research Institute, Lunuwila Sri Lanka, \\ ' Dept. of Crop Science, Faculty of Agriculture, University of Peradeniya, \\ Peradeniya, Sri Lanka
}

\begin{abstract}
Coconut Research Institute of Sri Lanka (CRISL) has designed and established twenty-six coconut-based agroforestry models in different agroecological regions of smallholder coconut farmers' fields commencing 1987. This study evaluates the conformity of four selected models with the existing resource base of smallholder coconut farmers and elicits their perceptions on these models. The selected models include: mixed farming for Wet Zone (model 1), mixed cropping for Wet Zone (model 2), mixed farming for Wet Intermediate Zone (model 3 ) and intercropping for Wet Intermediate Zone (model 4), established respectively at Gaspe, Hanchapola, Katuneriya and Thulawala. Conformity of these models with the existing resource base of the farmers was analyzed by comparing labor and cash requirement of the models with the availability of these two resources at farmers' disposal while the farmers' perceptions were elicited through a survey using a structured questionnaire supplemented with informal discussions. Results revealed that all the selected agroforestry models conform with the existing cash resource base of the farmer at current scale of operation, but not so with the family labor supply. However, both these resources may turn out to be limiting constraints once the current scale of operation is expanded. The farmers' expressed mix perceptions on agroforestry models in terms of model layout, crop composition, suitability to socioeconomic circumstances etc, with an overall positive assessment implying that the models developed by the CRISL are acceptable for them.
\end{abstract}

\section{INTRODUCTION}

In Sri Lanka, majority of coconut lands are maintained as monocultures. This gives relatively low returns to the farmer per unit land area than its potential under intensified land use systems. Coconut-based agroforestry i.e. cropping and farming with coconut plantations, is one of the strategies to efficient utilization of coconut lands and it also provides many socioeconomic advantages. 
In mature coconut lands, nearly $75 \%$ of land area is available for agroforestry models while the corresponding figure in young coconut plantations, i.e. plantations of $>0-5$ years, is $80-90 \%$ (Liyanage, 1994).

Liyanage and Dassanayake (1991) have identified several coconut-based agroforestry systems, which include intercropping, mixed cropping, coconutbased alley cropping, coconut-based mixed farming and cultivation of multipurpose trees in coconut lands. Based on these and past experiences, the Coconut Research Institute of Sri Lanka (CRISL) has developed some coconut-based agroforestry models for coconut growers to increase land productivity and farmers' income. These models were established in farmers' fields of different agro-ecological regions (Table A1).

Profitability of these models is one of the major determinants influencing the adoption of them by smallholder farmers'. However, profitability of a technology alone is not a sufficient condition to take the adoption decision, especially by smallholder coconut farmers. The technology must be conform to the existing resource base and the diverse objectives of farmers. Therefore, evaluation of the conformity of these crop models to resource base and multiple objectives of farmers is an important area of research as a pre requisite to recommend these models to the farmers.

\section{Objectives of the Study}

The objective of this study is to evaluate the social acceptability of agroforestry models developed by the CRISL for smallholders in the Wet and Intermediate Wet Zones of Sri Lanka. The specific objectives are:

i. To determine the conformity of the agroforestry models with the existing resource base of the selected farmers, and

ii. To investigate the farmers' perceptions on the selected agroforestry models.

\section{METHOD}

\section{Data}

CRISL has established 26 coconut-based agroforestry models in smallholder farmers' fields of different agro ecological regions to investigate the agronomic performance, economic feasibility and the social acceptability

\footnotetext{
1 This aspect was explored elsewhere by the same authors and concluded that the annual gross margins and Net Present Valucs of selected four agroforestry models are higher than coconut monoculture.
} 
of these models by smallholder farmers. Table A1 presents the details of the established models.

A control plot involving only monocrop coconuts has been maintained in each of the models for comparison. Input and output data of each model were collected once a month from the time of establishment.

Of the 26 models, 4 models (a crop model and a crop livestock integrated model each from Wet Zone and Intermediate Wet Zone as detailed in Table 1) were selected for the detailed study considering the time and other resource limitations for the present study. Representation of both crop and crop-livestock integrated models for the detailed analysis forms the basis of selecting these four models.

\section{Farmers' perceptions on agroforestry models}

The farmers' perceptions on the selected four models were elicited using a one-page questionnaire with open-ended questions supplemented with informal discussions. The main sections of the questionnaire were: (i) type of land use, (ii) land use history, (iii) comments on layout of the model, (iv) comments on composition of the component crops in the model, such as species and population density, ( $v$ ) suitability of the model to the socioeconomic condition of the farmer (scale of inputs and management), (vi) suitability of the model to the soil conditions in relation to selection of species and varieties and resource competition, (vii) suitability of the model to the agro-ecological region, (viii) acceptability of the model by farmers, (ix) importance of subsidies, $(x)$ household income and expenditure.

\section{Analytical Procedure}

\section{A. Conformity of the models with the existing resource base of farmers}

\section{a. Additional resource requirement}

Additional resource requirements were determined by comparing labor use and capital requirement of monocrop and agroforestry systems. Family man days (FMD), family women days (FWD), family child days (FCD), hired man-days (HMD), hired women days (HWD) and hired child days (HCD) were used for the comparison of labor use. 
Capital requirements of agroforestry systems and monocrop systems were calculated using the cost involved for hiring of labor, purchasing of material inputs, hiring of machinery and transport. Although an opportunity cost is involved for family labor (FL), out of pocket expenditure is not incurred for $F L$, so it was not considered for calculating capital requirement.

\section{b. Monthly labor requirement and availability}

Monthly labor requirement for agroforestry and monocrop systems and household availability in man-days were assessed. Representative data only for two years from each model were used for this assessment although several years' data for the complete monitoring period were available.

\section{c. Cash requirement and availability}

The cash availability for each farmer was computed using the income and expenditure data collected from informal discussions with them. The cash availability was compared with the capital requirement of each agroforestry model. As there was a high variation in capital requirement in different years of each model, minimum and maximum capital invested for the models were used for comparisons.

\section{B. Farmers' perceptions}

Information gathered from informal discussions with farmers was analyzed descriptively to determine the farmers' perceptions on different attributes of agroforestry models.

\section{RESULTS AND DISCUSSION}

\section{A. Conformity of Models with Existing Resource Base of Farmers}

Two resources, i.e. labor and cash were considered. Section (a) and (b) discuss the results respectively with regard to labor and cash. 


\section{a. Comparison of labor use}

\section{a.i Annual labor requirement}

\section{Model 1}

Table 2: Shows the labor use by agroforestry and coconut monocrop systems of model 1.

\begin{tabular}{|c|c|c|c|c|c|c|c|c|}
\hline \multirow[t]{2}{*}{ Year } & \multicolumn{4}{|c|}{ Mlxed farming } & \multicolumn{3}{|c|}{ Coconut monocrop } & \multirow[b]{2}{*}{ HWD } \\
\hline & FMD & FWD & HMD & HWD & FMD & FWD & HMD & \\
\hline $\mathbf{I}$ & 74.75 & 1.75 & 115 & 35 & 39.75 & 1.75 & 68 & 35 \\
\hline 2 & 63.75 & - & 7 & - & 3.75 & - & 13 & - \\
\hline 3 & 62 & 0.25 & 7.5 & - & 8 & 0.25 & 7.5 & - \\
\hline 4 & 77.5 & 2.25 & 5 & - & 9.25 & 0.75 & 5 & - \\
\hline 5 & 73 & 5 & 10 & 0.75 & 2.75 & - & 15 & 0.75 \\
\hline Total & $\begin{array}{r}351 \\
(70.2)\end{array}$ & $\begin{array}{r}9.25 \\
(1.85)\end{array}$ & $\begin{array}{r}144.5 \\
(29)\end{array}$ & $\begin{array}{l}35.75 \\
(7.15)\end{array}$ & $\begin{array}{r}63.5 \\
(12.7)\end{array}$ & $\begin{array}{r}2.75 \\
(0.55)\end{array}$ & $5(21.7)$ & $\begin{array}{l}35.75 \\
(7.15)\end{array}$ \\
\hline
\end{tabular}

Notes: FMD- family man days; FWD- family women days; HMD- hired man days;

HWD - hired women days.

Figures in parentheses are the averages.

Source: Mixed farming model, Gaspe (1992-1996).

Mixed farming model utilizes higher amount of labor than coconut monocrop. For instance, nearly six times family man days (FMD) over monoculture. This reveals that mixed farming would match to farmers either with a greater availability of family labor or with a greater access and affordability to hired labor. Contributions of family women days (FWD) for total labor use in both systems are low and both systems use hired women days (HWD) in almost equal quantities. Labor use in first year is high in both systems than other years. Utilization of FMDs and HMDs in agroforestry system was respectively $236 \%$ and $33 \%$ higher than coconut monoculture.

\section{Model -2}

Agroforestry system shows a higher labor use (nearly double) than coconut monoculture (Table 3).

Normally perennial crops utilize high amount of labor during the initial growth phase and they need at least ten years to give an attractive yield. During the first five years, total labor utilization of mixed cropping system is considerably high while in the coconut monocrop it is low and equally distributed between years. Use of FMDs, FWDs and HMDs were respectively $146 \%, 628 \%$ and $116 \%$ higher than coconut monocrop. Very few or virtually no HWDs and CDs were used for coconut monoculture and a very little of CDs were used for the mixed cropping system. 
Table 3: Comparison of labor use in mixed cropping and coconut monoculture - model 2

\begin{tabular}{|c|c|c|c|c|c|c|c|c|c|c|c|c|}
\hline \multirow{2}{*}{ Year } & \multicolumn{6}{|c|}{ Mixed cropping } & \multicolumn{6}{|c|}{ Coconut monocrop } \\
\hline & FMD & FWD & FCD & HMD & HWD & $\mathrm{HCD}$ & FMD & FWD & $\overline{F C D}$ & HMD & HWD & HCD \\
\hline 1 & 2.65 & & - & 21 & 7 & - & 2.14 & - & - & 7 & - & - \\
\hline 2 & 12.52 & 2.5 & - & 17 & 7 & - & 8.63 & 2.5 & - & 7 & - & - \\
\hline 3 & 14.37 & 8.5 & - & 11 & 10 & 4 & 5.72 & 0.5 & - & 6 & 1 & - \\
\hline 4 & 26.54 & 7.5 & - & 13 & - & - & 7.21 & - & - & 5 & - & - \\
\hline 5 & 13 & $8.75^{\circ}$ & 1.5 & 21 & 4.25 & - & 6.5 & 0.5 & - & 5.5 & - & - \\
\hline 6 & 9.25 & 1 & - & 4.75 & - & - & 4.25 & - & - & 5.5 & - & - \\
\hline 7 & 9.25 & 1.5 & - & 4.5 & 1 & - & 3.5 & - & - & 5 & - & - \\
\hline 8 & 7 & 1 & - & 9.75 & 1 & - & 2 & 1 & - & 8.5 & - & - \\
\hline 9 & 11.75 & 2 & - & 7.5 & 3.25 & - & 3.25 & - & - & 1 & - & - \\
\hline Total & $\begin{array}{r}106 \\
(12)\end{array}$ & $\begin{array}{c}32.7 \\
5(4)\end{array}$ & $\begin{array}{r}1.5 \\
(0.16)\end{array}$ & $\begin{array}{r}109.5 \\
(12)\end{array}$ & $\begin{array}{r}33.5 \\
(3.72)\end{array}$ & $\begin{array}{r}4 \\
(0.44)\end{array}$ & $\begin{array}{r}43 \\
(4.8)\end{array}$ & $\begin{array}{r}4.5 \\
(0.5)\end{array}$ & - & $\begin{array}{r}50.5 \\
(5.6)\end{array}$ & $\begin{array}{r}1 \\
(0.11)\end{array}$ & - \\
\hline
\end{tabular}

Notes: FMD- family man days; FWD- family women days; HMD- hired man days; HWD - hired women days.

Figures in parentheses are the averages.

Source: Mixed cropping model, Hanchapola (1987-1996).

\section{Model 3}

Total labor requirement for agroforestry system of model - 3 was greatly higher than for its monocrop coconut counterpart (Table 4). Equally, the labor requirement of the agroforestry system was greatly higher than the labor supply by the household. Therefore, the farmer has to depend on HL. Of the total labor force, contribution of family labor is higher in mixed farming system whereas approximately equal contribution of $\mathrm{HL}$ and $\mathrm{FL}$ can be seen as regards to coconut monocrop. Mixed farming model had utilized 8.5 and 23.6 times more FMD and FWD respectively as compared with coconut monocrop. Labor use in coconut monocrop system is almost uniformly distributed except in first two years. Dairy management and coffee needed higher labor inputs initially. Therefore, this model is economically more viable with households having a greater supply of family labor or for households having greater accessibility and affordability to hired labor. 
Table 4: Comparison of labor use in mixed farming and monoculture -model 3

\begin{tabular}{|c|c|c|c|c|c|c|c|c|c|c|c|c|}
\hline \multirow[t]{2}{*}{ Year } & \multicolumn{7}{|c|}{ Mixed farming } & \multicolumn{5}{|c|}{ Coconut monocrop } \\
\hline & $\overrightarrow{F M D}$ & FWD & FCD & HMD & HWD & HCD & FMD & FWD & $\overline{F C D}$ & HMD & HWD & $\mathrm{HCO}$ \\
\hline 1 & 67.75 & 72.25 & - & 61 & 12 & 7 & 23 & 3 & - & - & 2 & - \\
\hline 2 & 127.5 & 148.5 & - & 22 & 4 & - & 22 & 5 & - & - & - & - \\
\hline 3 & 142 & 157.25 & 23.5 & 9 & 2 & - & 7.5 & 3 & - & 20 & - & - \\
\hline 4 & 135.5 & $101.5 \cdot$ & - & 10 & 2 & - & 9 & 9.25 & - & 20 & - & - \\
\hline 5 & 66.5 & 75 & - & 4.5 & 4 & - & 5 & 3.5 & - & 20 & - & - \\
\hline 6 & 99.75 & 43 & - & 5.35 & 15.5 & - & 5.75 & 1.5 & - & 20 & - & - \\
\hline 7 & 9.25 & 4.75 & - & 6 & - & . & 4.25 & 0.25 & - & 24 & - & - \\
\hline Total & $\begin{array}{l}648.25 \\
(92.6)\end{array}$ & $\begin{array}{l}602.25 \\
(86)\end{array}$ & $\begin{array}{l}23.5 \\
(3.36)\end{array}$ & $\begin{array}{l}117.85 \\
(16.83)\end{array}$ & $\begin{array}{l}39.5 \\
(5.64)\end{array}$ & $7(1)$ & $\begin{array}{l}76.5 \\
\text { (11) }\end{array}$ & $\begin{array}{l}25.5 \\
.(3.64)\end{array}$ & - & $\begin{array}{l}104 \\
(14.8)\end{array}$ & $\begin{array}{l}2 \\
(0.28\end{array}$ & - \\
\hline
\end{tabular}

Notes: FMD- family man day; FWD-family women day; HMD- hired man day; HWD - hired women day.

Figures in parentheses are the averages.

Source: Mixed farming model, Ihala Katuneriya (1989-1997).

\section{Model 4}

In model 4, coconut monocrop and mixed cropping systems had utilized mainly $\mathrm{HL}$ and the labor requirement of the mixed cropping system is greater than coconut monocrop (Table 5). Total labor requirement for both cropping systems has declined with time. The contribution of HMD and HWD for mixed cropping was respectively $126 \%$ and $620 \%$ greater than the monocrop. For all models, contribution of child labor was negligible.

Table 5: Comparison of labor use for mixed cropping and monoculture model 4

\begin{tabular}{|c|c|c|c|c|c|c|c|c|c|c|c|c|}
\hline Year & \multicolumn{6}{|c|}{ Mixed cropping. } & \multicolumn{6}{|c|}{ Coconut monocrop } \\
\hline & FMD & FWO & FCD & HMD & HWD & HCD & FIMD & FWO & FCD & 7 HMD & HWO & HCO \\
\hline 1 & . & - & . & 80.51 & 16.25 & 2 & - & - & . & 31.5 & & . \\
\hline 2 & - & - & - & 20.64 & 18.75 & 1 & - & - & - & 11 & 0.75 & . \\
\hline 3 & 3 & - & - & 20.25 & 4.5 & - & - & - & - & 8.5 & - & - \\
\hline 4 & - & - & - & 21.5 & 3.3 & - & - & - & - & $n$ & 3.5 & . \\
\hline Tatal & $\begin{array}{l}3 \\
(0.76)\end{array}$ & - & - & $\begin{array}{l}142.9 \\
(35.72)\end{array}$ & $\begin{array}{l}45 \\
\text { (11.25) }\end{array}$ & $3(0.75)$ & - & - & - & $\begin{array}{l}63 \\
\text { (15.75) }\end{array}$ & $\begin{array}{l}8.25 \\
(150)\end{array}$ & . \\
\hline
\end{tabular}


Notes: FMD- family man days; FWD- family women days; HMD- hired man days; HWD - hired women days.

Figures in parentheses are the averages.

Source: Mixed cropping model, Thulawala (1991-1995).

\section{a.ii. Monthly labor requirement and availability}

\section{Model 1}

As Figure 1 shows, the labor requirement of the coconut monocrop during May to November of first year was met by the household, whereas the labor requirement of the agroforestry system was higher than the availability during the same period. There was a labor peak in December for both agroforestry and coconut monocrop systems, during which time the available labor was significantly less than the requirement. This was due to the establishment of husk pits. The labor requirement of the agroforestry system from January to April was met by the supply, whereas the labor requirement for coconut monoculture during the same period was less than the supply. All these suggest that coconut monoculture is feasible with the available labor whereas agroforestry system requires more labor than the supply from the household. Therefore, HL component plays an important role in the adoption of the agroforestry systems.

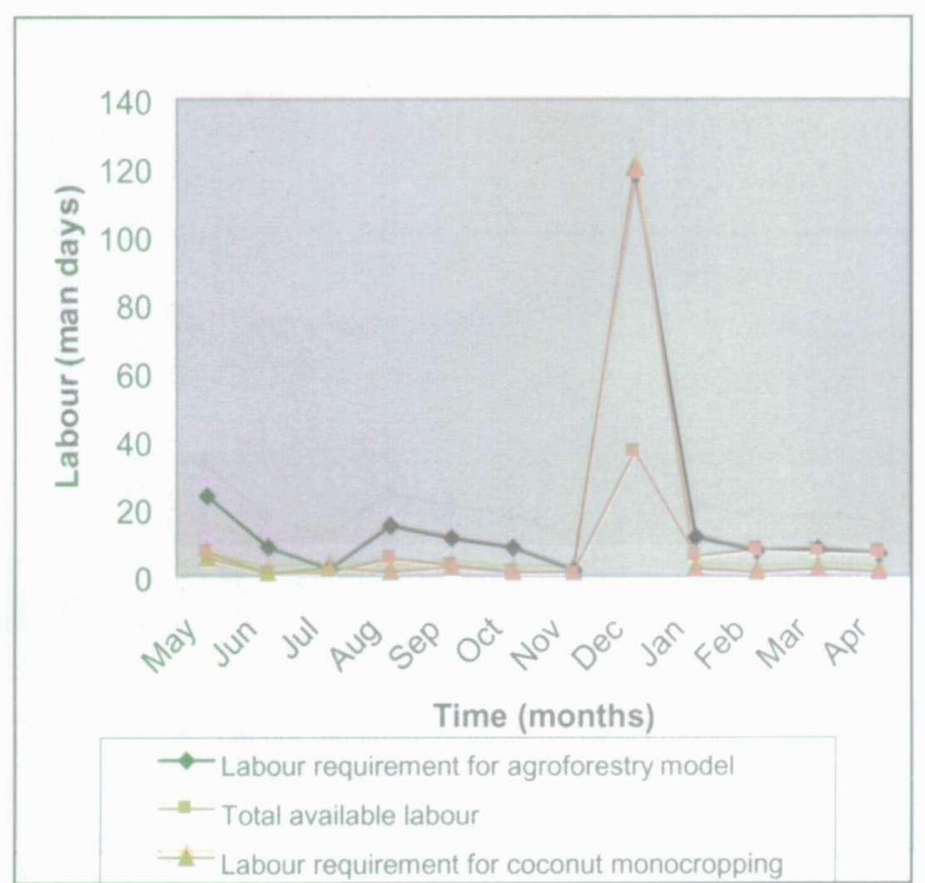

Figure 1 Monthly labor requirement and availability in the first year of model -1 
As Figure 2 shows, labor requirement of the coconut monoculture system during the $4^{\text {th }}$ year was less than the supply. There was a labor peak in December for coconut monocrop due to the weeding. There were labor peaks in May, August, November and April in agroforestry system, during which the labor demand could not be met by the household supply (Figure 2).

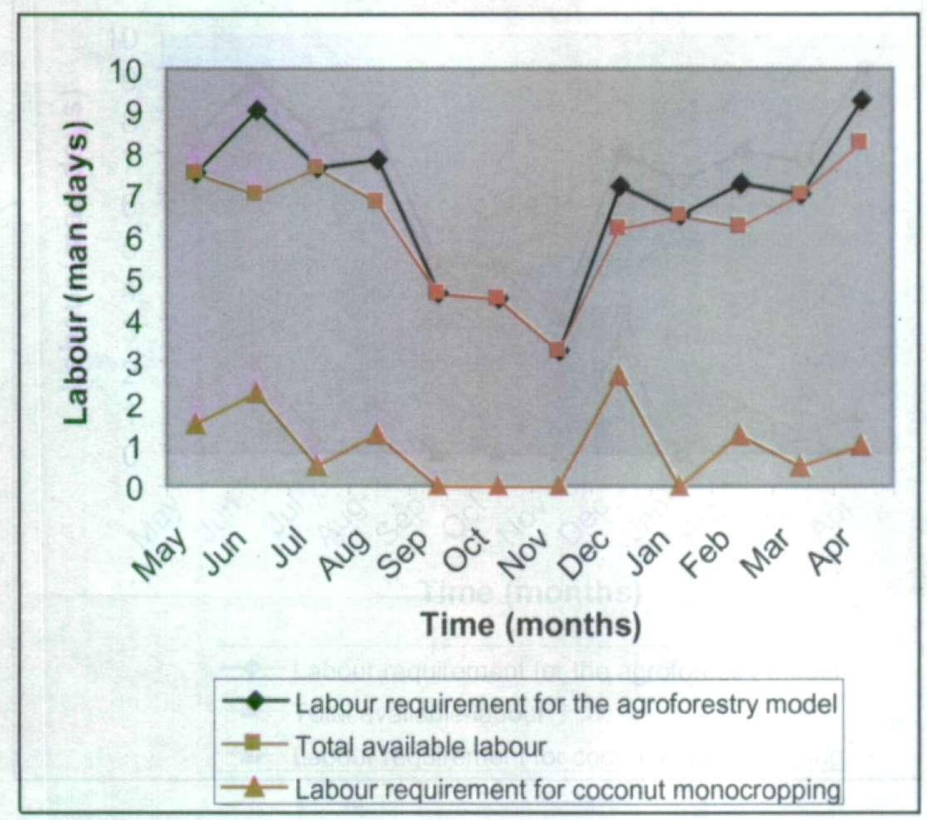

Figure 2 Monthly labor requirement and availability in the $4^{\text {th }}$ year of model 1

In summery, agroforestry system of the model -1 is less feasible with the available household labor, so farmer has to depend on hired labor to some extent.

\section{Model 2}

Figure 3 shows the monthly labor requirement of year 4 of: a) agroforestry system, b) coconut monoculture system, and c) monthly labor supply by the household. Labor requirement of two different cropping systems and supplied by the household show a discernible pattern of variation. The coconut monocrop system shows a labor peak in September due to higher weeding requirement. Agroforestry system shows three labor peaks in June, August and November. Whereas labor peaks of agroforestry system in the $7^{\text {th }}$ year occurred in March and September (Figure 4). Coconut monocrop system shows the highest labor peak in May of $7^{\text {th }}$ year due to the weeding requirement. 
In all the years, labor requirement of the coconut monocrop system was less than the agroforestry system as well as total available labor in the household. This emphasizes that coconut monoculture is feasible under existing family labor supply. Whereas the labor requirement of the agroforestry system has marginally exceeded the supply in some months, necessitating the hiring of labor.

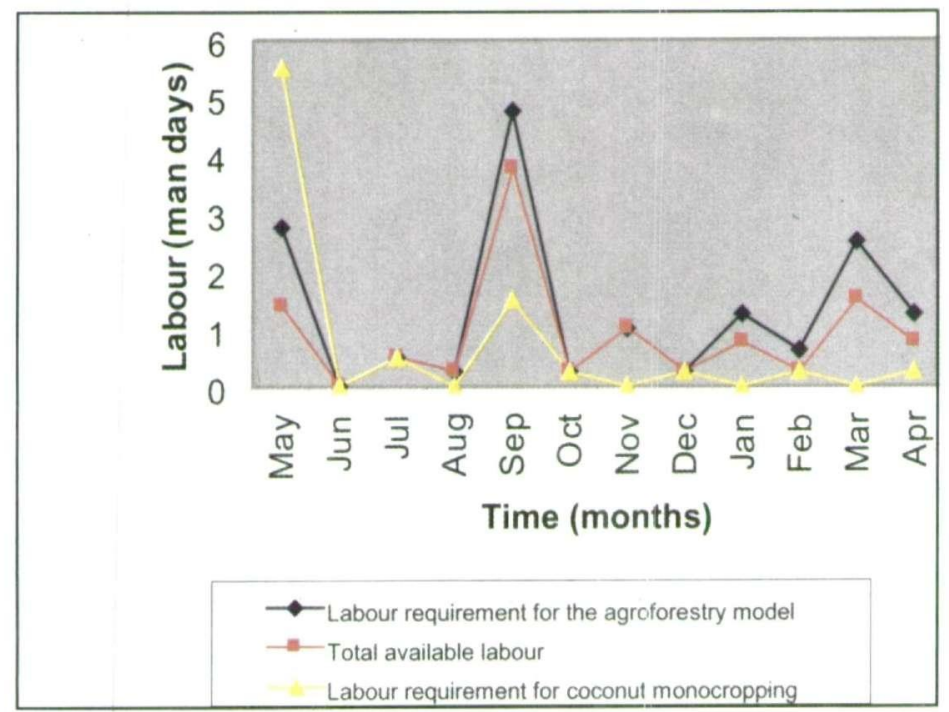

Figure 3 Monthly labor requirement and availability in the $4^{\text {th }}$ year of model 2

\section{Model 3}

Figure 5 and 6 show the monthly labor requirement and availability during the $1^{\text {st }}$ and $7^{\text {th }}$ year of model -3 , respectively. Except in May of $7^{\text {th }}$ year, labor demand of coconut monoculture was well below the supply from the household. Meanwhile, the labor demand of the agroforestry system was marginally higher than the household supply except in May of both $1^{\text {st }}$ and $7^{\text {th }}$ year. In year one, this labor peak for agroforestry system (about 94 man days) was due to the establishing of crops and pastures. 


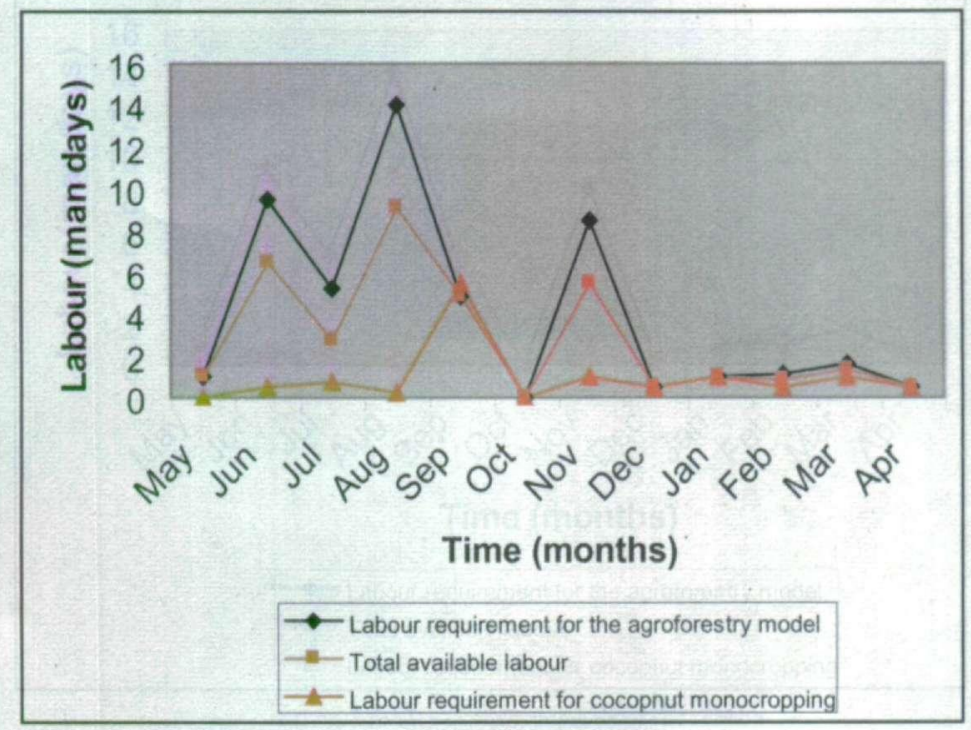

Figure 4 Monthly labor requirement and availability in the $7^{\text {th }}$ year of model 2

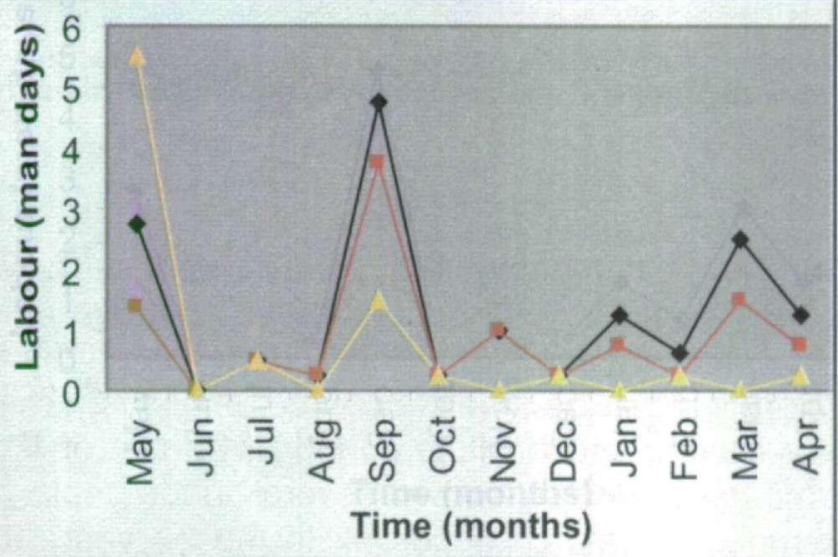

Figure 5 Monthly labor requirement and availability in the '1st year of model 3 


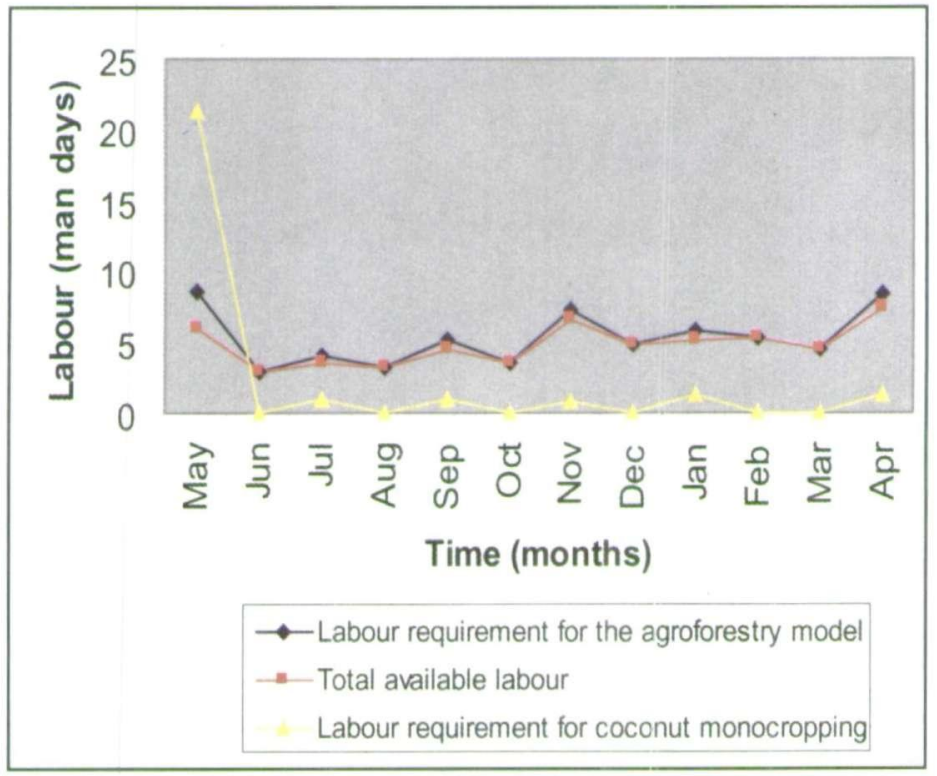

Figure 6 Monthly labor requirement and availability in the 7 th year of model 3

\section{Model 4}

Figures 7 and 8 show the monthly labor requirement and availability, of model 4 during the $1^{\text {st }}$ and $2^{\text {nd }}$ year respectively. Total available labor was zero in both years, which means farmer totally depends on the HL because he is involved in farming only as an extra source of income. There was only one labor peak for coconut monoculture during November of $1^{\text {st }}$ year. In the same year, agroforestry system shows several labor peaks in October, November, December and March (Figure7). In the $2^{\text {nd }}$ year, both systems demanded low labor as compared with year 1 . Figure 7 Monthly labor requirement and availability in the 1 st year of model 4

Agroforestry system shows several labor peaks within the $2^{\text {nd }}$ year (Figure 8). Since farmer totally depends on the HL for both cropping systems, cash is required to purchase the labor. So, cash availability influences the adoption of the model. 


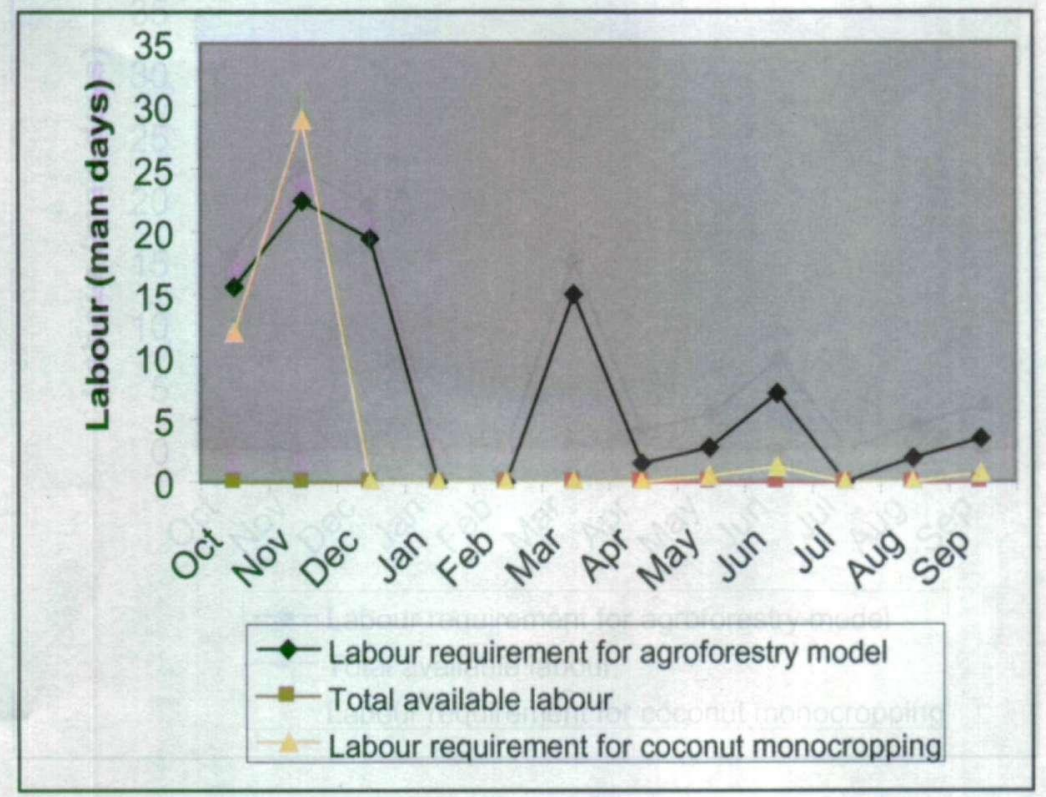

Figure 7 Monthly labor requirement and availability in the 1st year of model 4

b. Comparison of cash requirement

\section{Model 1}

Table 6 compares the cash requirement of coconut monocrop and mixed farming system of model -1 for different inputs, namely $\mathrm{HL}$, material inputs, transport services and machinery rentals. 


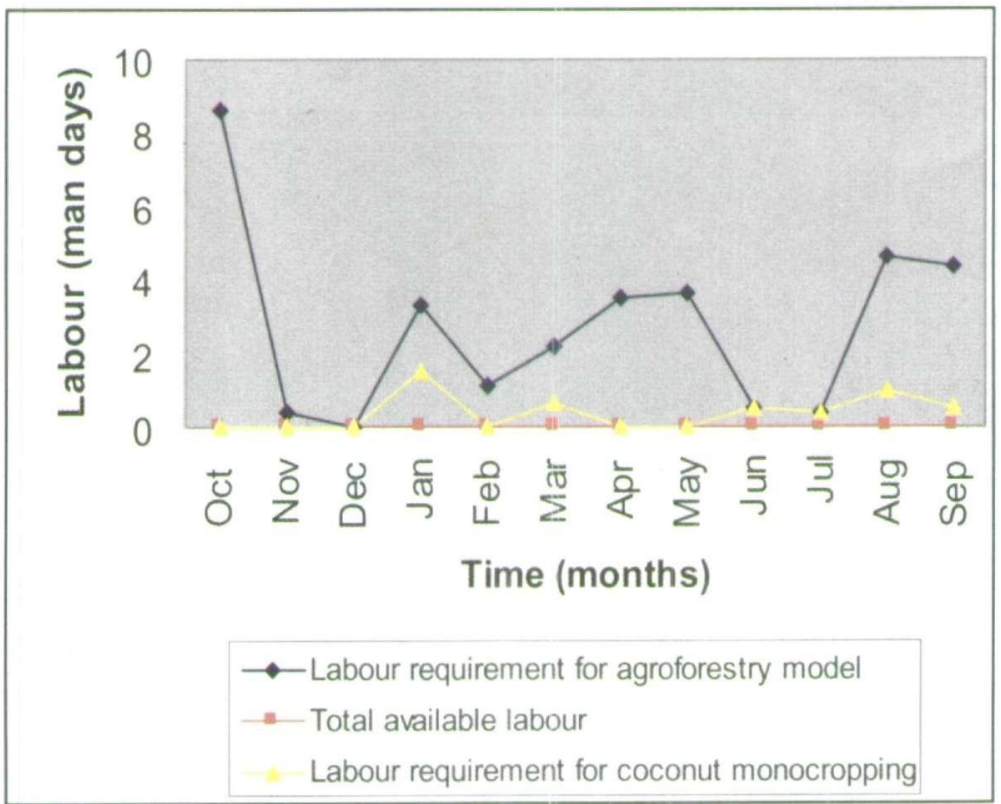

Figure 8 Monthly labor requirement and availability in the 2 nd year of model 4

Table 6: Comparison of cash requirement- model 1 (Rs/ac)

\begin{tabular}{|c|c|c|c|c|c|c|c|c|}
\hline \multirow[t]{2}{*}{ Year } & \multicolumn{4}{|c|}{ Mixed farming } & \multicolumn{4}{|c|}{ Coconut monocrop } \\
\hline & $\mathrm{HL}$ (Rs) & $\begin{array}{c}\text { Material } \\
\text { cost (Rs) }\end{array}$ & $\begin{array}{l}\text { Transport } \\
\text { cost (Rs) }\end{array}$ & $\begin{array}{l}\text { Machinery } \\
\text { cost (Rs) }\end{array}$ & HL (Rs) & $\begin{array}{l}\text { Material } \\
\text { cost (Rs) }\end{array}$ & $\begin{array}{l}\text { Transport } \\
\text { cost (Rs) }\end{array}$ & $\begin{array}{l}\text { Machinery } \\
\text { cost (Rs) }\end{array}$ \\
\hline 1 & 77275.00 & 21915.40 & 1527.85 & 1350.00 & 4202.50 & 2050.90 & 52.00 & 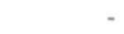 \\
\hline 2 & 210.00 & 6817.00 & 284.26 & 850.00 & 570.00 & - & 36.00 & - \\
\hline 3 & 330.00 & 11432.34 & 118.70 & - & 330.00 & 1100.34 & 36.00 & - \\
\hline 4 & 175.00 & 9958.3 & 257 & - & 175.00 & 1505.30 & 25.00 & - \\
\hline 5 & 770.00 & 25747.35 & 936.25 & & 620.00 & 1950.00 & 37.25 & - \\
\hline Total & $\begin{array}{r}78760.00 \\
(15752.00)\end{array}$ & $\begin{array}{r}75870.00 \\
(15174.00) \\
\end{array}$ & $\begin{array}{r}3124 \\
(625.00) \\
\end{array}$ & $\begin{array}{l}2200.00 \\
(440.00)\end{array}$ & $\begin{array}{r}5897.00 \\
(1179.00) \\
\end{array}$ & $\begin{array}{r}6606.00 \\
(1321.00) \\
\end{array}$ & $\begin{array}{r}186.00 \\
(37.00) \\
\end{array}$ & - \\
\hline
\end{tabular}

Note : $\mathrm{HL}$ - Hired Labor.

1 US\$ = Rs 64.32 as on May 1998.

Figures in parentheses are the averages.

Source : Mixed farming model, Gaspe (1992-1996).

In the first and the second year, machinery cost was involved only for the mixed farming system. Five-year total material, transport and hired labor costs were respectively $11.5,16.8$ and 13.35 times higher in mixed farming system than coconut monoculture. In both systems, total cash requirement has increased with time. Material costs for coconut monoculture were higher over other cash requirement in each year except in first year. Material cost was also prominent over the other costs in mixed farming system, except in the first year, during which rent hired labor cost was the highest. 
Total cash requirement of the agroforestry system of model-1 has exceeded that of coconut monocrop. Therefore the farmer must have a greater accessibility to cash to adopt agroforestry systems.

\section{Model 2}

Table 7 compares the cash requirement of coconut monocrop and mixed cropping systems of model 2.

Table 7: $\quad$ Comparison of cash requirement - model 2 (Rs/0.5ac)

\begin{tabular}{|c|c|c|c|c|c|c|c|c|}
\hline \multirow[t]{2}{*}{ Year } & \multicolumn{4}{|c|}{ Mixed cropping } & \multicolumn{4}{|c|}{ Coconut monocrop } \\
\hline & HL & $\begin{array}{l}\text { Material } \\
\text { cost }\end{array}$ & $\begin{array}{l}\text { Transport } \\
\text { cost }\end{array}$ & $\begin{array}{l}\text { Machinery } \\
\text { cost }\end{array}$ & $H L$ & $\begin{array}{l}\text { Materlal } \\
\text { cost }\end{array}$ & $\begin{array}{l}\text { Transport } \\
\text { cost }\end{array}$ & $\begin{array}{l}\text { Machinery } \\
\text { cost }\end{array}$ \\
\hline 1 & 1025.00 & 1141.25 & 38.50 & ${ }^{-}$ & 275.00 & 360.00 & 31.50 & - \\
\hline 2 & 700.00 & 1666.5 & 63.88 & - & 345.00 & 350.00 & 30.63 & $\cdot$ \\
\hline 3 & 1035.00 & 979.50 & 17.50 & - & 410.00 & - & - & - \\
\hline $\begin{array}{l}4 \\
5\end{array}$ & $\begin{array}{r}1462.50 \\
1933.75\end{array}$ & $\begin{array}{r}2982.70 \\
7479.22\end{array}$ & $\begin{array}{r}2494.85 \\
680.86\end{array}$ & - & $\begin{array}{r}750.00 \\
482.00\end{array}$ & $\begin{array}{r}561.00 \\
934.32\end{array}$ & $\begin{array}{r}23.10 \\
12.21\end{array}$ & : \\
\hline $\begin{array}{l}6 \\
7\end{array}$ & $\begin{array}{r}467.50 \\
590.00\end{array}$ & $\begin{array}{l}2727.47 \\
4030.72\end{array}$ & $\begin{array}{l}66.20 \\
64.94\end{array}$ & : & $\begin{array}{r}515.00 \\
590.00\end{array}$ & $\begin{array}{l}1090.98 \\
1363.45\end{array}$ & $\begin{array}{l}25.00 \\
25.08\end{array}$ & : \\
\hline 8 & 2313.75 & 2762.78 & 70.05 & . & 2107.50 & 1687.80 & 29.05 & - \\
\hline 9 & 1245.00 & 2185.46 & 91.60 & - & 400.00 & & & - \\
\hline Total & $\begin{array}{r}10772 \\
\text { (1197) }\end{array}$ & $\begin{array}{r}25956 \\
(2884) \\
\end{array}$ & 3588 (399) & $\cdot$ & $\begin{array}{r}5874 \\
(653) \\
\end{array}$ & $\begin{array}{r}6348 \\
(705) \\
\end{array}$ & $177(20)$ & - \\
\hline
\end{tabular}

Note : Such practices as coconut harvesting, fertilizing, digging of husk pits are often carried out on contract basis. So, labor use for these practices in man-days has not been included.

1 US\$ = Rs 64.32 as on May 1998.

Figures in parentheses are the averages.

Source : Mixed cropping model, Hanchapola (1987-1996).

The 9-year total cash requirement of mixed cropping was higher than the coconut monocrop and there was no machinery cost for any of the cropping systems. HL, material cost and transport costs were respectively 2, 4 and 20 times greater in mixed cropping than coconut monoculture.

In each year of mixed cropping system also, $\mathrm{HL}$, material and transport costs were greater than that of monocrop. The total cash requirement in each year has fluctuated in both models.

\section{Model 3}

Cash requirement of the coconut monocrop and mixed farming systems of model -3 has fluctuated highly (Table 8 ). 


\begin{tabular}{|c|c|c|c|c|c|c|c|c|}
\hline year & \multicolumn{4}{|c|}{ Mixed farming } & \multicolumn{4}{|c|}{ Coconut monocrop } \\
\hline & HL (Rs) & $\begin{array}{c}\text { Material } \\
\text { cost } \\
\text { (Rs) }\end{array}$ & $\begin{array}{c}\text { Transpor } \\
\text { t cost } \\
\text { (Rs) }\end{array}$ & $\begin{array}{l}\text { Machinery } \\
\text { cost } \\
\text { (Rs) }\end{array}$ & $\begin{array}{l}\mathrm{HL} \\
\text { (Rs) }\end{array}$ & $\begin{array}{l}\text { Material } \\
\text { cost (Rs) }\end{array}$ & $\begin{array}{c}\text { Transport } \\
\text { cost } \\
\text { (Rs) }\end{array}$ & $\begin{array}{l}\text { Machinery } \\
\text { cost (Rs) }\end{array}$ \\
\hline $\begin{array}{l}1 \\
2\end{array}$ & $\begin{array}{l}4360.00 \\
1705.00\end{array}$ & $\begin{array}{r}8394.00 \\
12701.16\end{array}$ & 668.98 & - & $\begin{array}{l}640.00 \\
245.00\end{array}$ & $\begin{array}{r}1480.00 \\
10718.04\end{array}$ & 55.00 & - \\
\hline 3 & 1420.00 & 25140.50 & 709.20 & - & 2270.00 & - & - & - \\
\hline 4 & 1775.50 & 23756.17 & 527.31 & - & 2403.00 & 12439.15 & 122.49 & - \\
\hline 5 & 1697.50 & 14973.23 & 485.20 & - & 2670.00 & 5542.23 & 58.20 & - \\
\hline 6 & 2610.00 & 12055.36 & 482.23 & - & 3070.00 & 7070.88 & 58.20 & - \\
\hline 7 & 1235.00 & 8423.12 & 448.80 & - & 3395.00 & 5577.88 & 58.20 & - \\
\hline Total & $\begin{array}{r}14803.00 \\
(2115)\end{array}$ & $\begin{array}{r}105443.00 \\
(15063)\end{array}$ & $\begin{array}{r}3574.00 \\
(510)\end{array}$ & - & $\begin{array}{r}14693.00 \\
\text { (2099) }\end{array}$ & $\begin{array}{r}42828.00 \\
(6118)\end{array}$ & $\begin{array}{r}463.00 \\
(66)\end{array}$ & - \\
\hline
\end{tabular}

Note : 1 US $\$=$ Rs 64.32 as on May 1998 .

$\mathrm{HL}$ - Hired Labor.

Figures in parentheses are the averages.

Source : Mixed farming model, Ihala Katuneriya (1989-1997).

The highest labor cost in the mixed farming system has occurred in the first year. Then it has reduced and remained with a low variation. But in coconut monocrop system, cash requirement for $\mathrm{HL}$ has increased yearly. This was due to the labor requirement for weeding. Normally weeding cost is reduced when agroforestry models are adopted. In both cropping systems, material cost has exceeded the HL cost and transport cost in each year. HL cost of both cropping systems in later years was nearly same despite the fact that agroforestry systems are known to be labor intensive. This is because the household supplies the rest of the additional labor requirement of agroforestry system.

\section{Model 4}

Monoculture and mixed cropping systems require high amount of cash during the first year, but in both systems the cash requirement has reduced and remained at a low range thereafter (Table 9).

However, these values were higher in mixed cropping system than monoculture. Machinery cost was only involved in mixed cropping system for the land preparation for establishing pineapple. The $\mathrm{HL}$ cost, material and transport costs were 2, 9 and 9 times respectively higher in mixed farming than coconut monoculture. 
Table 9: Comparison of cash requirement (Rs/0.5ac) - model 4

\begin{tabular}{|c|c|c|c|c|c|c|c|c|}
\hline Year & & Mixe & cropping & & & Coconi & monocrop & \\
\hline 1 & $\begin{array}{c}\mathrm{HL} \\
6106.99\end{array}$ & $\begin{array}{c}\text { Material } \\
\text { cost } \\
14641.43\end{array}$ & $\begin{array}{c}\text { Transport } \\
\text { cost } \\
2607.30\end{array}$ & $\begin{array}{l}\text { Machingry } \\
\text { cost } \\
650.00\end{array}$ & $\begin{array}{c}\text { HL } \\
4149.50\end{array}$ & $\begin{array}{c}\text { Materlal } \\
\text { cost } \\
759.00\end{array}$ & $\begin{array}{c}\text { Transport } \\
\text { cost } \\
231.50\end{array}$ & $\begin{array}{c}\text { Machinery } \\
\text { cost }\end{array}$ \\
\hline 2 & 2299.56 & 3843.28 & 81.10 & - & 952.50 & 702.80 & 30.75 & - \\
\hline 3 & 2158.75 & 3504.23 & 72.25 & - & 928.75 & 595.10 & 18.55 & - \\
\hline 4 & 2650.00 & 3302.24 & 73.20 & - & 1425.00 & 665.00 & 28.00 & - \\
\hline Total & $\begin{array}{r}13215.00 \\
(3304)\end{array}$ & $\begin{array}{r}5291.00 \\
(6323)\end{array}$ & $\begin{array}{r}2834.00 \\
(708)\end{array}$ & $\begin{array}{r}650.00 \\
(162)\end{array}$ & $\begin{array}{r}7456.00 \\
(1864)\end{array}$ & $\begin{array}{r}2722.00 \\
(680)\end{array}$ & $\begin{array}{r}309.00 \\
\text { (77) }\end{array}$ & - \\
\hline
\end{tabular}

Note $\quad: 1$ US $\$=$ Rs 64.32 as on May 1998.

$\mathrm{HL}$ - Hired Labor.

Figures in parentheses are the averages.

Source : Mixed cropping model, Thulawala (1991-1995).

We next compare the cash demand by the different agroforestry models with corresponding cash supply by households.

Table 10: Cash availability in households and cash requirement by different agroforestry models

\begin{tabular}{lcccc}
\hline $\begin{array}{l}\text { Cropping } \\
\text { model }\end{array}$ & $\begin{array}{l}\text { Household } \\
\text { income } \\
\text { (Rs/year) }\end{array}$ & $\begin{array}{l}\text { Household } \\
\text { expenditure } \\
\text { Rs/year) }\end{array}$ & $\begin{array}{l}\text { Cash availability } \\
\text { (Rs/year) }\end{array}$ & $\begin{array}{l}\text { Cash requirement (minimum and } \\
\text { maximum) for agroforestry model } \\
\text { (Rs/year) }\end{array}$ \\
\hline Model 1 & 164592 & 60000 & 104592 & $\mathbf{8 1 6 1 - 1 0 2 0 6 8}$ \\
Model 2 & 90000 & 42000 & 48000 & $2032-10094$ \\
Model 3 & 126000 & 60000 & 66000 & $10107-27270$ \\
Model 4 & 168000 & 71100 & 96900 & $5735-24006$ \\
\hline
\end{tabular}

Note : 1 US $\$=$ Rs 64.32 as on May 1998 .

Source : Data collected from on-farm models (1987-1996).

The cash requirement does not exceed the cash availability of the farmer in all the models. Therefore, the farmer can meet additional labor requirement and other resource requirement for the agroforestry models. One should notice that only a fraction of the monocrop coconut land, was taken for the mixed farming in all four models. For instance, in model 1 , only 1 ac out of 5 ac was taken for mixed farming. So, what the results reveal is that mixed farming models conform to the existing resource base of the farmers at the above scale of operation.

\section{B. Farmers' Perceptions on Agroforestry Models}

Although the perceptions of the selected four farmers were elicited with a reasonable depth, obviously generalizations on social acceptability cannot 
be drawn from this limited sample. Subject to this caveat, the following results are presented. Quite often, farmers have multiple objectives. As shown in Table 11, the farmer in crop-livestock integrated model 1 has adopted his cropping system to gain various products such as milk, cattle manure and coconuts.

\section{Table 11: Farmers' perceptions on different attributes of the models}

\begin{tabular}{|c|c|c|c|c|}
\hline Attribute & Model 1 & Model 2 & Model 3 & Model 4 \\
\hline - Farmer objectives & $\begin{array}{l}\text { products and } \\
\text { cash }\end{array}$ & satisfaction & cash & cash \\
\hline - Land use history & $\begin{array}{l}\text { natural } \\
\text { pasture with } \\
\text { coconut }\end{array}$ & $\begin{array}{l}\text { coconut } \\
\text { monocrop }\end{array}$ & $\begin{array}{l}\text { natural } \\
\text { pasture with } \\
\text { coconut }\end{array}$ & $\begin{array}{l}\text { coconut } \\
\text { monocrop }\end{array}$ \\
\hline $\begin{array}{l}\text { - Layout of the model } \\
\text { - } \quad \text { Suilability to socio-economic } \\
\text { condition }\end{array}$ & $\begin{array}{l}\text { SF } \\
\text { SF } \\
\text { SF }\end{array}$ & $\begin{array}{l}\text { NSF } \\
\text { NSF } \\
\text { SF }\end{array}$ & $\begin{array}{l}\text { SF } \\
\text { NSF } \\
\text { SF }\end{array}$ & $\begin{array}{l}\text { SF } \\
\text { SF } \\
\text { SF }\end{array}$ \\
\hline $\begin{array}{l}\text { - Suitability to soil condition } \\
\text { - } \quad \text { Suitability to agroecological region } \\
\text { - } \quad \text { Imperall acceptance of the model } \\
\text { Establishmen of subsidies- } \\
\text {-Maintenance }\end{array}$ & $\begin{array}{l}\text { SF } \\
\text { SF } \\
\text { accept } \\
\text { Important }\end{array}$ & $\begin{array}{l}\text { SF } \\
\text { SF } \\
\text { accept } \\
\text { important }\end{array}$ & $\begin{array}{l}\text { SF } \\
\text { SF } \\
\text { accept } \\
\text { important }\end{array}$ & $\begin{array}{l}\text { SF } \\
\text { SF } \\
\text { accept } \\
\text { not much } \\
\text { important }\end{array}$ \\
\hline
\end{tabular}

Notes : SF-Satisfactory, NSF-Non satisfactory.

Source : Survey on farmers' perceptions, 1999.

Farmer of the $2^{\text {nd }}$ model adopted the cropping system for his satisfaction (see Table 11) after seeing a well-managed coconut + pepper intercropping model. The other farmers adopted the models to gain an extra income (Table 11). Therefore, it is clear that the farmers' objectives of adopting agroforestry systems are diverse, ranging from income generation, selfsupply of farm products, to deriving mental satisfaction.

Natural pasture with coconut was the previous land use of the model 1 and 3 , while coconut monocrop was the previous land use of the model 2 and 4 (Table 11). Except the farmer of model 2, all the others were satisfied about the layouts of their models. In model 2, the farmer believes that spacing between the pepper row is not enough and it creates competition for resources. He is also of the view that pepper and gliricidia can be damaged, when coconut fronds fall on the ground. The farmers of model 2 and 3 were not much satisfied about the composition of crops in the models. Second farmer was of the view that the pepper density is too much in the model, while the $3^{\text {rd }}$ farmer says fruit crops like papaw could have been incorporated into the model during the initial stages, to compensate the low return during that stage. All the farmers agree with the models in terms of the suitability to their socio-economic conditions, soil condition of the field and agro-ecological region. All the farmers generally accept the models. 
Farmers of the model 1,2 and 3 emphasized the importance of the subsidies to motivate the farmers in adopting agroforestry systems. They indicate that this cash support is important, especially during the initial stages of the cropping system, to compensate the high cost involvement, whereas these considerations were less important for the farmer in model 4.

\section{CONCLUSIONS}

This study evaluated the conformity of four selected coconut-based agroforestry models developed by the Coconut Research Institute of Sri Lanka, with the existing resource base of smallholder coconut farmers and elicited their views on these models. These models were: $i)$ mixed farming for Wet Zone (model 1), ii) mixed cropping for Wet Zone (model 2), iii) mixed farming for Wet Intermediate Zone (model 3) and iv) intercropping for Wet Intermediate Zone (model 4), established respectively at Gaspe, Hanchapola, Katuneriy and Thulawala. The study concluded the followings.

- All the agroforestry systems require additional resources (labor and capital for the establishment and maintenance of their components), as compared with coconut monocrop. Agroforestry system in each of the four models constitutes only a small fraction of the entire monocrop coconut land belonging to respective farmers and hence the scales of operation of agroforestry systems were relatively low. Even under this low scale of operation, family labor supply was not adequate for most agroforestry systems, implying that they do not match with the household labor availability. However, the cash requirement for agroforestry systems were less than the availability of each farmer, which implies that the agroforestry systems conforms to the cash resource of the farmer, given the small-scale of operation. However, if these farmers wish to expand the scale of operation of these agroforestry systems, their cash resource base may also turn out to be a limiting factor.

- Models 1 and 4 were readily acceptable to farmers while models 2 and 3 required slight modifications to make them socially acceptable.

- In model 2 and 3, perennial intercrops were less labour and cash intensive and hence these agroforestry systems would ideally match to part-time coconut growers, whose main concern would be their high caliber professions or other businesses. 


\section{REFERENCES}

Liyanage, M.de.S. and Dassanayake, K.B. (1991). Experience in coconutbased farming systems in Sri Lanka. In: Advances in coconut research and development, (Eds.) M. K. Nair, H. H. Khan, P. Gopalsunderam and E. V. V. Bhaskara Rao. New Delhi Oxford and IBH publishing company, $357-367$.

Liyanage, M.de.S. (1994). Coconut-based agroforestry in Sri Lanka. In: Trees and Tree farming. (Eds.) P. K. Thompson, Peekay Books, Kerala.

\section{ACKNOWLEDGEMENT}

We are grateful to Dr. (Mrs) C. Jayasekera, Director of the CRISL, for approval to publish this paper. Authors also wish to acknowledge the early hard work of Messrs. KD D Appuhamy, E M Gunerathnebanda and Ryle Silva in establishing the on-farm agroforestry models. Support of Mrs. Nilmini Jayalath and Mr M. J. I. Costa is gratefully acknowledged. 


\section{ANNEX I}

Table A1: On-farm coconut-based agroforestry models established by CRISL

\begin{tabular}{|c|c|c|c|c|c|c|}
\hline $\begin{array}{l}\text { Serial } \\
\text { no }\end{array}$ & $\begin{array}{l}\text { Agro- } \\
\text { ecologic } \\
\text { al region }\end{array}$ & District & $\begin{array}{l}\text { Soil } \\
\text { type }\end{array}$ & Location & $\begin{array}{l}\text { Type } \\
\text { model }\end{array}$ & Components \\
\hline $\begin{array}{l}1 \\
2 \\
3 \\
4 \\
5\end{array}$ & $\begin{array}{l}W 1 Z \\
W 1 Z \\
W Z \\
W Z \\
W Z\end{array}$ & $\begin{array}{l}\text { Puttalam } \\
\text { Puttalam } \\
\text { Gampaha } \\
\text { Gampaha } \\
\text { Gampaha }\end{array}$ & $\begin{array}{l}\text { LG } \\
\text { LG } \\
\text { LG } \\
\text { LG } \\
\text { LG }\end{array}$ & $\begin{array}{l}\text { Kahatawila } \\
\text { Thulawaia } \\
\text { Walpita } \\
\text { Hanchapola } \\
\text { Gaspe }\end{array}$ & $\begin{array}{l}\text { Intercropping } \\
\text { Mixed crop } \\
\text { Mixed crop } \\
\text { Mixed crop } \\
\text { Mixed farm }\end{array}$ & $\begin{array}{l}\text { Banana, ginger } \\
\text { Pepper, lime,Ginger } \\
\text { Pepper, banana, ginger } \\
\text { Pepper, coffee, ginger } \\
\text { Pasture, NFT's, local x jersey }\end{array}$ \\
\hline $\begin{array}{l}6 \\
7\end{array}$ & $\begin{array}{l}\text { WZ } \\
\text { WZ }\end{array}$ & $\begin{array}{l}\text { Gampaha } \\
\text { Gampaha }\end{array}$ & $\begin{array}{l}\text { LG } \\
\text { LG }\end{array}$ & $\begin{array}{l}\text { Banduragoda } \\
\text { Mirigama }\end{array}$ & $\begin{array}{l}\text { Intercropping } \\
\text { Mixed farm }\end{array}$ & $\begin{array}{l}\text { Banana, ginger } \\
\text { Brachiaria nuziziensis, } \\
\text { NFT, gliricidia, pepper, } \\
\text { coffee, Sindhi x Jersey }\end{array}$ \\
\hline 8 & $W \mid z$ & Puttalam & SL & Ihalakatuneriya & $\begin{array}{l}\text { Mixed } \\
\text { farming }\end{array}$ & $\begin{array}{l}\text { Coffee,Guini B, B.milliformis, } \\
\text { pueraria, Glinicidia, Sindhi X } \\
\text { Jersey }\end{array}$ \\
\hline $\begin{array}{l}9 \\
10\end{array}$ & $\begin{array}{l}\text { WIZ } \\
\text { WIZ }\end{array}$ & $\begin{array}{l}\text { Puttalam } \\
\text { Puttalam }\end{array}$ & $\begin{array}{l}\text { LG } \\
\text { LG }\end{array}$ & $\begin{array}{l}\text { Thulawala } \\
\text { Kahatawila }\end{array}$ & $\begin{array}{l}\text { Intercropping } \\
\text { Mixed crop }\end{array}$ & $\begin{array}{l}\text { Pineapple, ginger, banana } \\
\text { Banana, pepper, ginger, } \\
\text { coffee }\end{array}$ \\
\hline 11 & WZ & Gampaha & LG & Divulapitiya & Mixed crop & $\begin{array}{l}\text { Banana, pepper, yams, } \\
\text { coffee }\end{array}$ \\
\hline $\begin{array}{l}12 \\
13\end{array}$ & $\begin{array}{l}\text { WZ } \\
\text { WI,IL1 }\end{array}$ & $\begin{array}{l}\text { Gampaha } \\
\text { Puttalam }\end{array}$ & $\begin{array}{l}\text { LG } \\
\text { LG }\end{array}$ & $\begin{array}{l}\text { Mirigama } \\
\text { Pothuwatawana }\end{array}$ & $\begin{array}{l}\text { Mixed crop } \\
\text { Mixed crop }\end{array}$ & $\begin{array}{l}\text { Pepper, coffee } \\
\text { Pepper, coffee, banana, } \\
\text { ginger }\end{array}$ \\
\hline $\begin{array}{l}14 \\
15\end{array}$ & $\begin{array}{l}\text { Wh3 } \\
\text { WL3 }\end{array}$ & $\begin{array}{l}\text { Gampaha } \\
\text { Gampaha }\end{array}$ & $\begin{array}{l}\text { LG } \\
\text { LG }\end{array}$ & $\begin{array}{l}\text { Divulapitiya } \\
\text { Walpita }\end{array}$ & $\begin{array}{l}\text { Mixed crop } \\
\text { Intercropping }\end{array}$ & $\begin{array}{l}\text { Pepper, coffee } \\
\text { Banana }\end{array}$ \\
\hline $\begin{array}{l}16 \\
17 \\
18 \\
18 \\
20\end{array}$ & $\begin{array}{l}\text { WL3 } \\
\text { WL3 } \\
\text { WL3 } \\
\text { IL1 } \\
\text { IL1 }\end{array}$ & $\begin{array}{l}\text { Gampaha } \\
\text { Gampaha } \\
\text { Puttalam } \\
\text { Puttalam } \\
\text { Puttalam }\end{array}$ & $\begin{array}{l}\text { LG } \\
\text { LG } \\
\text { LG } \\
\text { LG } \\
\text { LG }\end{array}$ & $\begin{array}{l}\text { Walpila } \\
\text { Udulla } \\
\text { Katuneriya } \\
\text { Kahatawila } \\
\text { Rathmalagara }\end{array}$ & $\begin{array}{l}\text { Intercropping } \\
\text { Mixed crop } \\
\text { Mixed crop } \\
\text { Mixed crop } \\
\text { Mixed } \\
\text { farming }\end{array}$ & $\begin{array}{l}\text { Pineapple } \\
\text { Ginger, pepper, coffee, yam } \\
\text { Pineapple, ginger, cashew } \\
\text { Pepper, coffee } \\
\text { NFT's, pasture, goat }\end{array}$ \\
\hline $\begin{array}{l}21 \\
22 \\
23 \\
26\end{array}$ & $\begin{array}{l}\text { IL1 } \\
\text { IL1 } \\
\text { WL3 } \\
\text { IL3 }\end{array}$ & $\begin{array}{l}\text { Kurunegala } \\
\text { Gampaha } \\
\text { Gampaha } \\
\text { Puttalam }\end{array}$ & $\begin{array}{l}\text { LG } \\
\text { LG } \\
\text { LG } \\
\text { SL }\end{array}$ & $\begin{array}{l}\text { Deegalla } \\
\text { Divulapitiya } \\
\text { Madurupitiya } \\
\text { Katuneriya }\end{array}$ & $\begin{array}{l}\text { Mixed crop } \\
\text { Mixed crop } \\
\text { Mixed farm } \\
\text { Mixed farm }\end{array}$ & $\begin{array}{l}\text { Cashew, lime, NFT's } \\
\text { Lime, mango } \\
\text { pepper, pasture, cattle } \\
\text { pepper, pasture }\end{array}$ \\
\hline
\end{tabular}

Key : LG-Lateritic Gravel, SL-Sandy Loam, NFT's-Nitrogen fixing trees. 